Tersedia online di: http://ejournal-balitbang.kkp.go.id/index.php/jra

\title{
PERTUMBUHAN DAN SINTASAN LARVA DAN BENIH IKAN KERAPU SUNU Plectropomus leopardus TURUNAN KETIGA (F-3) DARI INDUK HASIL SELEKSI
}

\author{
Ahmad Muzaki ${ }^{\#}$, Sari Budi Moria Sembiring, Ida Komang Wardana, dan Haryanti
}

Balai Besar Riset Budidaya Laut dan Penyuluhan Perikanan

(Naskah diterima: 9 Desember 2016; Revisi final: 4 September 2017; Disetujui publikasi: 4 September 2017)

\begin{abstract}
ABSTRAK
Pertumbuhan dan sintasan larva dan benih kerapu sunu turunan ketiga (F-3) dari induk turunan kedua (F-2) hasil seleksi telah diamati di Balai Penelitian dan Pengembangan Budidaya Laut, Gondol. Induk F-2 diseleksi menggunakan marka indikator tumbuh cepat PL-03 (alel tunggal berukuran 370 bp). Penelitian ini bertujuan untuk mengevaluasi keragaan pertumbuhan dan sintasan larva dan benih kerapu sunu F-3 serta pewarisan sifat tumbuh cepat dari induk kerapu sunu (F-2) kepada benih kerapu sunu F-3. Pembenihan menggunakan induk kerapu sunu F-2 dengan sifat tumbuh cepat (membawa marka PL-03) dan tanpa sifat tumbuh cepat. Telur dan larva yang dihasilkan dipelihara sebagai turunan F-3 hingga berukuran benih dan dibesarkan selama 10 bulan pemeliharaan. Hasil pengamatan sintasan larva kerapu sunu F-3 dari induk membawa marka PL-03 adalah sebesar $10,6 \% \pm 9,1 \%$ sedangkan larva F-3 dari induk yang tidak membawa sifat tumbuh cepat hanya sebesar $2,7 \% \pm 1,7 \%$ Benih F-3 dari induk membawa marka PL-03 dapat dipanen saat mencapai ukuran 2,5-3,0 cm pada umur $38 \pm 2$ hari, sedangkan benih F-3 dari induk tanpa marka PL-03 pada umur $40 \pm 1$ hari. Selanjutnya benih kerapu sunu F-3 dari induk yang mempunyai marka PL-03 yang dipelihara selama 10 bulan memiliki laju pertumbuhan harian lebih baik $(3,11 \%)$ dibandingkan benih kerapu sunu F-3 tanpa marka PL-03 (3,01\%). Sintasan benih kerapu sunu F-3 dengan marka PL-03 tidak berbeda nyata dengan yang tidak mempunyai marka PL-03. Persentase benih F-3 turunan dari induk F-2 dengan sifat tumbuh cepat yang membawa marka PL-03 sebesar 45\%
\end{abstract}

\section{KATA KUNCl: pertumbuhan; sintasan; larva; benih; kerapu sunu turunan ketiga (F-3); marka indikator tumbuh cepat}

ABSTRACT: Thegrowth and survival rate of the third generation (F-3) larvae and fry produced from genetically selected coral trout (Plectropomus leopardus) broodstock. By: Ahmad Muzaki, Sari Budi Moria Sembiring, Ida Komang Wardana, and Haryanti

\begin{abstract}
The growth and survival rate of the third generation $(F-3)$ of coral trout grouper larvae and fry from the genetically selected broodstock were observed at the Institute for Mariculture Research and Development, Gondol. The F-2 broodstock were selected using the fast-growing marker indicator, PL-03 (single allele of $370 \mathrm{bp}$ in size). The aim of this study was to determine the growth performance and survival rate of larvae and fry of $\mathrm{F}-3$ coral trout groupers, as well as inheritance of fast growth trait from the F-2 broodstock to the F-3. The eggs and larvae of F-3 produced from F-2 broodstock with fast growth trait (having PL-03 marker) and without fast growth trait were reared to reach fry stage for 10 months. The results showed that the survival rate of the F-3 larvae from broodstock with PL-03 marker was $10.6 \% \pm 9.1 \%$ while $\mathrm{F}-3$ larvae from the broodstock without fast growth trait only reached $2.7 \% \pm 1.7 \%$ Fry (F3) with PL-03 marker reached the optimum harvest size of $2.5-3.0 \mathrm{~cm}$ at $38 \pm 2$ days old, while the F-3 fry of broodstock without PL-03 marker took relatively longer to reach that size (40 \pm 1 days age). The F-3 from the broodstock with PL-03 marker reared for 10 months had better growth rate $(3.11 \%$ compared to F-3 fry without PL03 marker $(3.01 \%$. The survival rate of F-3 fry with PL-03 marker was not significantly different to F-3 fry without PL03 marker. The percentage of F-3 fry from the broodstock of F-2 with fast growth trait was $45 \%$
\end{abstract}

\section{KEYWORDS: growth; survival rate; larvae; fry; coral trout grouper third generation; fast-growing marker} indicator

\footnotetext{
\# Korespondensi: Balai Besar Riset Budidaya Laut dan

Penyuluhan Perikanan. JI. Br. Gondol Kec. Gerokgak Kab.

Buleleng, Po. Box 140, Singaraja 81155, Bali, Indonesia.

Tel. + (0362) 92278

E-mail: gondolisme@ yahoo.com
} 


\section{PENDAHULUAN}

Tingginya permintaan pasar terhadap ikan kerapu sunu menyebabkan semakin intensifnya kegiatan penangkapan di alam yang berakibat pada penurunan populasinya di alam. Pengembangan budidaya ikan kerapu sunu merupakan alternatif solusi yang dapat dilakukan untuk mengurangi kegiatan penangkapan dan memenuhi permintaan pasar. Namun dalam perkembangannya masih menemui kendala dalam ketersediaan benih. Untuk mengatasi masalah tersebut, diperlukan penyediaan benih yang mencukupi baik dari segi kualitas maupun kuantitasnya. Sejak tahun 2005, penelitian kerapu sunu telah dilakukan dimulai dengan pemijahan induk kerapu sunu pada bak pemeliharaan (Suwirya, 2005).

Balai Besar Penelitian dan Pengembangan Budidaya Laut, Gondol telah melakukan upaya perbaikan sifat genetik ikan kerapu sunu untuk meningkatkan kualitas benih melalui aplikasi marka indikator tumbuh cepat (lokus PL-03 berukuran 370 bp) menggunakan metode microsatelit/SSRs (Simple Sequence Repeats) (Sembiring et al., 2012). Penggunaan marka indikator tumbuh cepat tersebut kemudian diaplikasikan lebih lanjut pada induk-induk ikan kerapu sunu hasil budidaya (turunan pertama dan kedua) sehingga akhirnya diperoleh benih ikan kerapu sunu dengan sifat fenotipe dan genotipe yang lebih baik. Pada tahun 2014 telah berhasil menghasilkan benih ikan kerapu sunu turunan ketiga (F-3) dengan sintasan larva (D-40) masih rendah yaitu $0 \% 4 \%$ (Sembiring et al., 2014). Oleh karena itu data dan informasi tentang benih kerapu sunu F-3 masih sangatlah terbatas, sehingga perlu dilakukan penelitian lanjutan untuk mendapatkan data dan informasi tentang larva dan benih kerapu sunu turunan ketiga.

Penelitian ini merupakan penelitian lanjutan dari tahun sebelumnya yaitu penggunaan marka tumbuh cepat (lokus PL-03) pada induk hasil budidaya dan evaluasi reproduksi induk kerapu sunu turunan kedua (Sembiring et al., 2014; 2015). Pada penelitian ini dilakukan pengamatan terhadap larva dan benih kerapu turunan $\mathrm{F}-3$ yang induknya telah diseleksi berdasarkan marka tumbuh cepat. Beberapa penelitian kerapu sunu yang telah dilakukan adalah pengaruh intensitas cahaya terhadap pertumbuhan dan perkembangan larva (Yoseda et al., 2008), perkembangan awal saluran cerna larva kerapu sunu (Qu et al., 2012), pemberian karotenoid (Kusumawati et al., 2015), penggunaan induk induk hasil budidaya F-1 (Suwirya et al., 2009).

Tujuan penelitian ini adalah untuk mengevaluasi keragaan pertumbuhan dan sintasan larva dan benih kerapu sunu F-3 serta penurunan sifat tumbuh cepat dari induk kerapu sunu (F-2) kepada benih kerapu sunu F-3.

\section{BAHAN DAN METODE}

Kegiatan ini dilaksanakan di Balai Besar Penelitian dan Pengembangan Budidaya Laut, Gondol-Bali pada Januari-November 2015. Metode penelitian meliputi pemeliharaan larva dan benih ikan kerapu sunu F-3, dan analisis marka tumbuh cepat.

\section{Hewan Uji}

Penelitian ini menggunakan telur hasil pemijahan alami induk-induk kerapu sunu turunan kedua (F-2) baik yang mempunyai sifat maupun tanpa sifat tumbuh cepat (PL-03), sedangkan benih yang digunakan dalam kegiatan ini merupakan hasil pemeliharaan larva kerapu sunu turunan ketiga ( $F-3$ ). Induk kerapu sunu $\mathrm{F}-2$ yang dipijahkan berumur 4 tahun dengan ukuran $49,3 \pm 4,8 \mathrm{~cm}$ dan $2,7 \pm 0,7 \mathrm{~kg}$ untuk induk $\mathrm{F}-2$ dengan sifat tumbuh cepat dan ukuran 47,6 $\pm 3,9 \mathrm{~cm}$ dan 2,3 $\pm 0,5 \mathrm{~kg}$ untuk induk F-2 tanpa sifat tumbuh cepat.

\section{Pemeliharaan Larva Kerapu Sunu Turunan Ketiga (F-3)}

Induk kerapu sunu F-2 membawa dan tidak membawa sifat tumbuh cepat (marka PL-03) masingmasing dipelihara pada bak berbeda. Induk kerapu sunu F-2 membawa marka PL-03 sebanyak 56 ekor, dan induk kerapu sunu F-2 yang tidak membawa marka PL-03 sebanyak 31 ekor. Pemijahan induk dilakukan secara alami setiap bulan pada fase bulan gelap/mati. Pemanenan telur dilakukan esok hari setelah induk memijah dan telur ditebar pada bak pemeliharaan larva (Suwirya et al., 2006). Kegiatan pemeliharaan larva kerapu sunu F-3 mengikuti meto de pemeliharaan larva kerapu (Sugama et al., 2012). Pemeliharaan larva kerapu sunu F-3 menggunakan bak beton volume 6 $\mathrm{m}^{3}$. Telur yang ditebar sebanyak 50.000 butir/bak. Penambahan Nannochloropsis sp. ke dalam media pemeliharaan larva dilakukan mulai umur 2 hari sampai 25 hari. Pakan awal larva setelah mulut terbuka yaitu pada umur 3 hingga 5 hari diberikan rotifer dengan kepadatan awal 5-6 ind/ml dan meningkat 7-10 ind./ $\mathrm{mL}$ rotifer pada umur 7-14 hari dan sekitar $15 \mathrm{ind} / \mathrm{ml}$ rotifer pada umur 15-30 hari. Rotifer diberikan dua kali sehari pada pagi dan sore dan jumlah pemberian disesuaikan dan dipertahankan sesuai dosis pemberian rotifer. Pakan buatan berupa mikropelet mulai diberikan setelah larva berumur 8 hari. Pakan buatan komersial yang berukuran kecil dengan ukuran partikel 200-400 $\mu \mathrm{m}$, pakan ditaburkan ke permukaan air dalam jumlah 2-3 g. Ukuran pakan meningkat menjadi 400$800 \mu$ m pada umur 30-45 hari. Pakan buatan diberikan 4-6 kali sehari.

Naupli Artemia sebanyak 0,2-0,5 ind./mL mulai diberikan setelah larva berumur 17 hari hingga larva 
berumur 35 hari yang diberikan 2 kali sehari (pagi dan sore). Setelah berumur 30 hari, larva diberi rebon 25 ind./L setiap pagi dan sore hari. Penjarangan dilakukan apabila larva dalam bak pemeliharaan terlihat terlalu padat dengan cara memindah larva kerapu sunu F-3 secara hati-hati ke bak pemeliharaan lainnya yang telah dipersiapkan sebelumnya. Larva kerapu sunu turunan ketiga (F-3) dapat dipanen setelah bermetamorfisis sempurna menjadi benih yang berukuran sekitar 2,5-3,0 cm.

Parameter yang diamati adalah tingkat penetasan $(\%$, sintasan larva dan benih $(\%$, jumlah benih yang dipanen (ekor), umur panen (hari), serta bobot tubuh dan panjang total benih ikan kerapu sunu F-3 pada saat panen.

\section{Pemeliharaan Benih Kerapu Sunu Turunan Ketiga (F-3)}

Benih hasil pemeliharaan larva kerapu sunu F-3 selanjutnya dipindahkan ke dalam bak pembesaran dengan kepadatan 1.000 ekor/bak. Bak yang digunakan adalah bak fiber volume $6 \mathrm{~m}^{3}$ sebanyak 10 buah (masing-masing 5 buah bak untuk pemeliharaan benih yang mempunyai dan tidak mempunyai sifat tumbuh cepat (marka PL-03) yang dilengkapi dengan 4 titik aerasi, pipa pemasukan dan pengeluaran air. Pembesaran benih menggunakan sistem sirkulasi air, dengan pergantian air sebanyak 200\%per hari. Pakan yang diberikan adalah pelet komersial kadar protein $40 \%$ dengan frekuensi pemberian 2 kali sehari pada pagi dan sore. Pakan diberikan sampai sekenyangnya. Setiap 2 minggu sekali benih ikan kerapu sunu ditreatmen menggunakan 50 ppm larutan formalin 37\% selama 15 menit dan dibilas dengan air tawar untuk menghilangkan parasit yang menempel di tubuh ikan. Sampling pertumbuhan (panjang total dan bobot tubuh) dilakukan pada 20 ekor ikan setiap bulan sekali. Pemeliharaan benih kerapu sunu F-3 pada kegiatan penelitian ini dilakukan selama 10 bulan pemeliharaan. Pada akhir pemeliharaan diamati laju pertumbuhan harian dan sintasan benih ikan kerapu sunu F-3 (Effendie, 1997).

\section{Analisis Marka Indikator Tumbuh Cepat}

Analisis marka tumbuh cepat PL-03 dilakukan pada 20 ekor benih kerapu sunu turunan ketiga dari induk kerapu sunu F-2 yang mempunyai sifat tumbuh cepat. Analisis sifat tumbuh cepat menggunakan metode mikrosatelit/SSRs (Simple Sequence Repeats) pada lokus PL-03 (Sembiring et al., 2012). Ekstraksi genome DNA dilakukan mengikuti meto de Ovenden (2000). Konfirmasi marka tumbuh cepat diawali dengan amplifikasi PCR pada target berukuran 370 bp
(Sembiring et al., 2012). Hasil amplifikasi kemudian diseparasi menggunakan mesin Sequencer ABI Prism yang dilakukan di $1^{\text {st }}$ Base Singapore. Parameter yang diamati adalah persentase individu dengan sifat tumbuh cepat pada benih kerapu sunu turunan ketiga (F-3).

\section{Analisis Data}

Data-data penetasan telur, sintasan larva, lama pemeliharaan larva, pertumbuhan, dan sintasan benih ikan kerapu sunu F-3 dianalisis menggunakan uji t pada taraf kepercayaan 95\% untuk membandingkan antara benih kerapu sunu F-3 dari induk yang mempunyai dan tidak mempunyai sifat tumbuh cepat (marka PL-03). Data disajikan dalam bentuk tabel dan grafik.

\section{HASIL DAN BAHASAN}

\section{Keragaan Pertumbuhan dan Sintasan Larva Kerapu Sunu Turunan Ketiga}

Data pemeliharaan larva kerapu sunu turunan ketiga disajikan pada Tabel 1. Dari 8 kali siklus pemeliharaan larva kerapu sunu F-3 selama tahun 2015, hanya periode penebaran bulan Januari yang menghasilkan benih kerapu sunu F-3, yaitu 3 bak menghasilkan benih kerapu sunu F-3 dari induk F-2 yang mempunyai lokus indikator tumbuh cepat (marka PL-03), dan 2 bak menghasilkan benih kerapu sunu F-3 dari induk F-2 tidak mempunyai lokus indikator tumbuh cepat. Tingkat penetasan telur kerapu sunu F-3 membawa dan tidak membawa markatidak berbeda nyata dengan F-3 dengan lokus indikator tumbuh cepat sebesar 62,7 $\pm 35,4 \%$ dan F-3 tanpa lokus indikator tumbuh cepat sebesar $88,2 \% \pm 10,5 \%$ Tingkat penetasan telur tergantung pada kualitas telur yang dihasilkan oleh induknya. Tingginya tingkat penetasan telur menunjukkan telur yang dihasilkan oleh induk kerapu sunu F-2 sudah cukup baik. Hal ini berkaitan erat dengan pemberian pakan segar dengan kualitas baik yang dilengkapi dengan vitamin $\mathrm{E}$ dan $\mathrm{C}$ selama pemeliharaan induk kerapu sunu F-2 (Setiadharma et al., 2008). Kualitas pakan induk yang digunakan sangat berpengaruh terhadap proses pematangan gonad dan kualitas telur yang dihasilkan (Watanabe, 1985; 1988).

Sintasan benih kerapu sunu F-3 dengan lokus indikator tumbuh cepat tidak berbeda nyata dengan pemeliharaan benih kerapu sunu F-3 tanpa lokus tumbuh cepat. Selain kualitas telur yang digunakan, keberhasilan pemeliharaan larva kerapu sunu juga dipengaruhi oleh metode pemeliharaan larva. Pemeliharaan larva kerapu sunu F-3 mengacu pada metode pembenihan ikan kerapu yang baik (Sugama 
Tabel 1. Keragaan tingkat penetasan telur, sintasan, dan lama pemeliharaan larva ikan kerapu sunu P. leopardus turunan ketiga (F-3) dari induk turunan F-2 hasil seleksi

Table 1. Performance of hatching rate, survival rate, and rearing period of coral trout grouper (P. leopardus) of the third generation ( $F-3$ ) derived from ( $F-2$ ) selected broodstock

\begin{tabular}{lcc}
\hline Parameter (Parameter) & $\begin{array}{c}\text { Benih turunan F-3 } \\
\text { dengan marka PL-03 } \\
\text { Third generation F-3 } \\
\text { larvae with PL-03 } \\
\text { marker }\end{array}$ & $\begin{array}{c}\text { Benih turunan F-3 } \\
\text { tanpamarka PL-03 } \\
\text { Third generation F-3 } \\
\text { larvae without PL-03 } \\
\text { marker }\end{array}$ \\
\hline Jumlah wadah pemeliharaan (bak) / Number of rearing tanks (pcs) & 3 & 2 \\
Tingkat penetasan (Hatching rate) (\%) & $62,7 \pm 35,4^{\text {a }}$ & $88,5 \pm 10,5^{\text {a }}$ \\
Sintasan larvae (Survival rate of fish fry) (\%) & $10,6 \pm 9,1^{\text {a }}$ & $2,7 \pm 1,7^{\text {a }}$ \\
Jumlah larva (ekor) (Number of larvae) (pcs) & $1.714 \pm 181^{\text {a }}$ & $3.975 \pm 2.935^{\text {a }}$ \\
Umur panen (hari)/ Harvested age (days) & $38 \pm 2^{\mathrm{a}}$ & $40 \pm 1^{\text {a }}$ \\
\hline
\end{tabular}

et al., 2012). Dengan menggunakan telur yang berkualitas dan metode pemeliharaan yang baik dapat meningkatkan keberhasilan pemeliharaan larva kerapu sunu. Sintasan larva kerapu sunu F-3 pada penelitian tahun ini lebih baik bila diibandingkan dengan sintasan larva F-3 pada penelitian sebelumnya yang hanya menghasilkan sintasan 0,3\% 4,0\% (Sembiring et al., 2014).

Umur panen larva kerapu sunu F-3 sangat dipengaruhi oleh pertumbuhan dan metamorfosis larva. Larva dipanen ketika bermetamorfosis secara sempurna menjadi benih ikan kerapu sunu berukuran sekitar 2,5-3 cm. Umur panen benih kerapu sunu F-3 dengan sifat tumbuh cepat tidak berbeda nyata dengan F-3 tanpa sifat tumbuh cepat, namun benih kerapu sunu f-3 dengan sifat tumbuh cepat dapat dipanen lebih cepat pada umur $38 \pm 2$ hari dibandingkan dengan benih F-3 tanpa sifat tumbuh cepat yang dipanen pada umur $40 \pm 1$ hari. Hal ini menunjukkan bahwa larva kerapu sunu F-3 membawa sifat tumbuh cepat bermetamorfosis menjadi benih dengan waktu yang lebih pendek dibandingkan dengan larva kerapu sunu F-3 tidak sifat tumbuh cepat. Pertumbuhan larva kerapu sunu F-3 yang bersifat tumbuh cepat juga lebih baik dibandingkan dengan pertumbuhan larva kerapu sunu F-3 tanpa sifat tumbuh cepat, seperti terlihat pada Gambar 1. Gambar 1 menunjukkan bahwa bo bot tubuh $(0,24 \mathrm{~g})$ dan panjang total $(2,28 \mathrm{~cm})$ benih kerapu sunu pada saat panen (umur 40 hari), dengan sifat tumbuh cepat lebih baik bila dibandingkan dengan benih kerapu sunu F-3 yang tanpa sifat tumbuh cepat.

\section{Keragaan Pertumbuhan dan Sintasan Benih Kerapu Sunu Turunan Ketiga (F-3)}

Data laju pertumbuhan dan sintasan benih ikan kerapu sunu turunan ketiga (F-3) yang dipelihara selama 10 bulan tersaji pada Tabel 2 .
Hasil analisis uji t terhadap pertumbuhan benih kerapu sunu F-3 selama 10 bulan pemeliharaan menunjukkan hasil yang berbeda nyata. Benih ikan kerapu sunu F-3 dengan sifat tumbuh cepat memiliki laju pertumbuhan harian lebih baik dibandingkan dengan benih ikan kerapu sunu tanpa sifat tumbuh cepat. Penelitian sebelumnya juga menyatakan bahwa induk kerapu sunu F-2 dengan sifat tumbuh cepat memiliki pertumbuhan bobot yang lebih baik $(7,2 \%)$ dibandingkan dengan induk kerapu sunu F2 tanpa sifat tumbuh cepat (Sembiring et al., 2014). Hal ini menunjukkan bahwa sifat tumbuh cepat pada lokus PL-03 dapat diaplikasikan dalam menghasilkan benihbenih ikan kerapu sunu tumbuh cepat. Seleksi menggunakan marka tumbuh cepat lebih baik bila dibandingkan dengan seleksi berdasarkan karakter fenotipik atau secara konvensional yang memiliki beberapa kelemahan diantaranya: 1. Memerlukan waktu yang cukup lama; 2 . Kesulitan memilih dengan tepat gen-gen yang menjadi target seleksi untuk diekspresikan pada sifat-sifat morfologi; 3. Rendahnya frekuensi individu yang diinginkan yang berada dalam populasi seleksi yang besar serta 4 . Fenomena pautan gen antara sifat yang diinginkan dengan sifat yang tidak diinginkan sulit dipisahkan khususnya saat melakukan persilangan. Oleh karena itu pemanfaatan marka DNA sebagai alat bantu seleksi lebih menguntungkan (lebih tepat, cepat dan relatif lebih hemat biaya dan waktu) (Holland, 2005). Sintasan benih kerapu sunu F-3 tidak berbeda nyata antara benih F-3 dengan marka PL-03 dan tanpa marka PL-03. Pemberian pakan yang baik dan cukup serta kualitas air pemeliharaan yang optimal mendukung tingginya sintasan benih kerapu sunu selama 10 bulan pemeliharaan. Selanjutnya benih-benih ikan kerapu sunu F-3 dengan sifat tumbuh cepat dipelihara hingga mencapai stadia induk yang siap digunakan untuk pembenihan ikan kerapu sunu. 


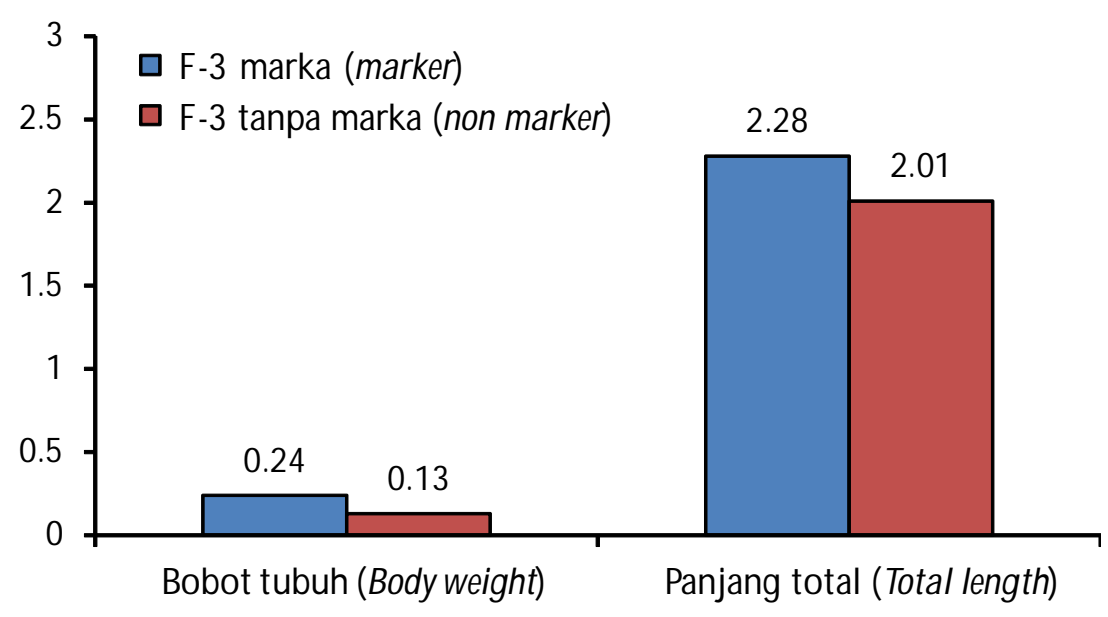

Gambar 1. Bobot tubuh dan panjang total benih kerapu sunu F-3 pada saat panen (umur 40 hari) dari induk yang membawa marka PL-03 (F-3 marka), dan tidak mempunyai marka (F-3 non marka).

Figure 1. Body weight and total length of F-3 coral trout fry at harvest (40 days age) from broodstock with PL-03 marker (F-3 marka) and without PL-03 marker (F-3 non marka).

\section{Analisis Marka Indikator Tumbuh Cepat}

Hasil analisis sifat tumbuh cepat dengan marka lokus PL-03 terhadap ikan kerapu sunu F-3 turunan dari induk $\mathrm{F}-2$ yang mempunyai sifat dan tanpa sifat tumbuh cepat ditunjukkan oleh Gambar 3. Marka PL03 merupakan marka alel tunggal yang berukuran 370 bp (Sembiring et al., 2014).

Hasil analisis lokus indikator tumbuh cepat PL-03 pada benih $\mathrm{F}-3$ turunan induk $\mathrm{F}-2$ yang membawa marka menunjukkan sebanyak $45 \%$ benih ( 9 sampel) masih membawa sifat tumbuh cepat yang diturunkan dari induk F-2 dan 55\%(11 sampel) menunjukkan tanpa sifat tumbuh cepat. Teramatinya marka tumbuh cepat PL-03 pada benih kerapu sunu turunan ketiga membuktikan bahwa sifat tumbuh cepat ini masih diwariskan oleh induknya yaitu kerapu sunu turunan kedua (F-2). Namun terjadi penurunan prosentase marka PL-03 pada kerapu sunu F-3 dibandingkan pada kerapu sunu F-2. Pada kerapu sunu turunan kedua, sebanyak 63,3\% (dari 90 ekor sampel) yang teramati membawa marka PL-03 (Sembiring et al., 2014). Pada penelitian sebelumnya, Haryanti et al. (2012) menggunakan penyandi tumbuh cepat pada locus PmMS-11A (144 bp) dengan metode mikrosatelit teramati sebanyak $60 \%$ pada benih turunan pertama udang windu Peneaus monodon. Pewarisan gen pertumbuhan dipengaruhi oleh banyak faktor yaitu diantaranya adalah faktor lingkungan. Hal ini sesuai dengan pendapat Falaki et al. (1997), yang menyatakan bahwa pertumbuhan merupakan sifat yang dikontrol oleh banyak gen, dengan demikian ekspresi dari setiap individu yang tumbuh cepat ditentukan oleh tiga komponen utama mencakup faktor genetik,

Tabel 2. Laju pertumbuhan harian dan sintasan benih kerapu sunu F-3 pada akhir pemeliharaan

Table 2. Growth rate and survival rate of coral trout fry at the end of experiment

\begin{tabular}{lcc}
\hline \multicolumn{1}{c}{$\begin{array}{c}\text { Kerapu sunu F-3 } \\
\text { F-3 coral trout }\end{array}$} & $\begin{array}{c}\text { Laju pertumbuhan harian } \\
\text { Growth rate }(\%)\end{array}$ & $\begin{array}{c}\text { Sintasan } \\
\text { Survival rate }(\%)\end{array}$ \\
\hline F-3 dengan marka PL-03 & $3,11 \pm 0,03^{\mathrm{a}}$ & $85,6 \pm 2,3^{\mathrm{a}}$ \\
F3 with PL -03 marker & $3,01 \pm 0,04^{\mathrm{b}}$ & $82,8 \pm 3,03^{\mathrm{a}}$ \\
F3 tanpa marka tumbuh cepat & F3 without PL - 03 marker & \\
\hline
\end{tabular}




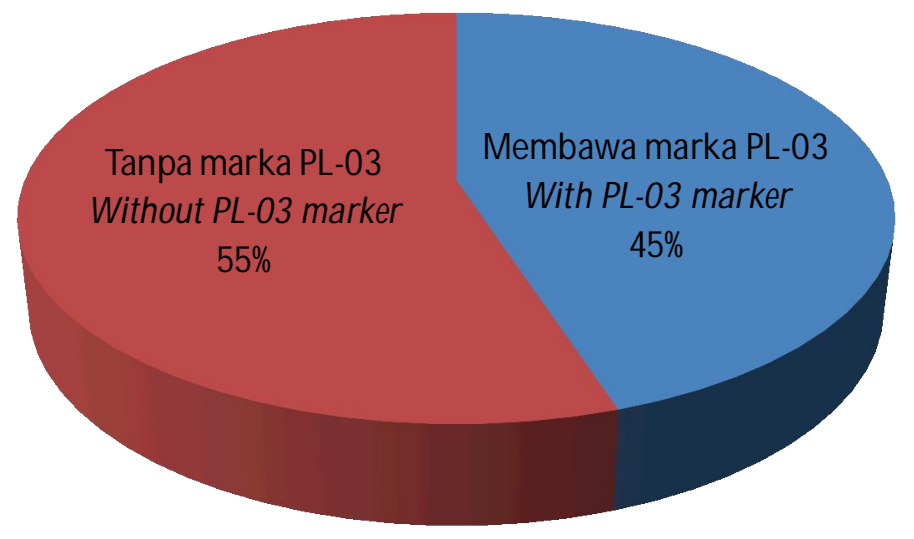

Gambar 3. Hasil analisis marka indikator tumbuh cepat pada benih kerapu sunu F-3 menggunakan metode mikrosatelit SSR

Figure 3. The result of fast growth marker indicator on F-3 coral trout fry using microsatelite/SSR method

lingkungan dan interaksi antara keduanya. Sifat kodominan pada lokus yang mengindikasikan tumbuh cepat seharusnya terdapat pada kedua alel yang diekspresikan pada individu heterozigot. Pada kasus dominan penuh, keturunan yang didapat pada F-2 akan menunjukkan perbandingan fenotipe dominan dan resesif $3: 1$ atau perbandingan genotipe 1:2:1. Namun, dari hasil penelitian yang diperoleh bahwa pewarisan sifat tumbuh cepat tidak mengikuti segregasi Mendel. $\mathrm{Hal}$ ini diduga terjadi penyimpangan semu hukum Mendel oleh adanya interaksi gen, sehingga menghasilkan rasio fenotipe yang berbeda dari dasar hukum Mendel. Ke depan, agar dapat dihasilkan benih secara massal dengan sifat tumbuh cepat (marka PL03), maka diperlukan pula induk kerapu sunu dengan jumlah yang lebih banyak (100 pasang induk) dengan sifat tumbuh cepat. Dengan demikian dapat diperoleh pewarisan sifat yang sesuai secara fenotipe maupun genotipe. Penggunaan gen penanda yang mengendalikan suatu karakter akan sangat membantu dalam efektivitas dan efisiensi proses seleksi, sehingga produk dan waktu seleksi dapat lebih valid dan singkat (Gupta \& Varshney, 2000) terutama dalam pembenihan kerapu sunu. Banyak gen teridentifikasi mempunyai potensi sebagai penciri genetik atau Marker-assisted Selection (MAS) yang akan bermanfaat dalam mempercepat kegiatan seleksi dari sifat produksi dan bernilai ekonomis. Gen-gen penyandi tumbuh cepat merupakan kandidat utama marka DNA untuk analisis pautan dengan Quantitatif Traits Loci (QTL) disebabkan signifikansi pengaruh biologisnya terhadap sifat-sifat bernilai ekonomis. Pemetaan QTL dengan menggunakan mikrosatelit untuk sifat pertumbuhan pada beberapa hewan vertebrata telah dilaporkan sejumlah peneliti seperti Maskur et al. (2007), Geldermann et al. (2006), Zhang et al. (2009), dan Chaoui et al. (2012).

\section{KESIMPULAN}

Kerapu sunu (Plectrophomus leopardus) turunan ketiga (F-3) yang membawa marka PL-03 (tumbuh cepat) menunjukkan pertumbuhan yang lebih baik dibandingkan dengan yang tanpa marka.

\section{UCAPAN TERIMA KASIH}

Penelitian ini dibiayai dari anggaran DIPA Balai Besar Penelitian dan Pengembangan Budidaya Laut Gondol tahun 2015. Terima kasih disampaikan kepada semua pihak yang telah membantu pelaksanaan penelitian ini terutama rekan-rekan teknisi litkayasa di pemeliharaan induk, pembenihan larva kerapu sunu, dan Laboratorium Bioteknologi BBPPBL.

\section{DAFTAR ACUAN}

Chaoui, L, Gagnaire, P.A., Guinand, B., Quignard, J.P., Tsigenopoulos, C., Kara, M.H., \& Bonhomme, F. (2012). Microsatellite length variation in candidate genes correlates with habitat in the gilthead sea bream Sparus aurata. Molecular Ecology, 21(22), 5497-5511.

Falaki, M., Gengler, N., \& Sneyers, M. (1997). Relationships of polymorphisms for growth hormone receptor gene with milk production traits for 
Italian Holstein-Friesian bulls. Journal Dairy Science. 79,1446-1453.

Geldermann, H., Mer, M.R., Kuss, W., \& Bartenschlager, H. (2006). OLA-DRB1 microsatellite variants are associated with ovine growth and reproduction traits. Genetics Selection Evolution. 38, 431-444.

Gupta, P.K. \& Varshney, R.K. (2000). The developmentand use of microsatellite markers for genetic analysis and plant breeding with emphasis on bread wheat. Euphytic,. 113, 163-185.

Haryanti, Mahardika, K., Fachrudin, Wardana, I.K., Permana, I G.N., \& Sembiring, S.B.M. (2012). Penggunaan gen penyandi tumbuh cepat dalam produksi benih udang windu Penaeus monodon. Jurnal Riset Akuakultur, 7(3), 345-358.

Holland, J.B. (2005). Implementation of molecular Marker for Quantitative Traits in Breeding Programs Challenges and Opportunities. Training $M$ anual on Advances in M arker-Asisted Selection Workshop, 21-24 February, IRRI, Los Banos, Filipina.

Kusumawati, D., Ismi, S., Asih, Y.N., Muzaki, A., Haryanti, \& Giri, N.A. (2015). Penggunaan karotenoid sebagai sumber pigmentasi warna merah pada larva kerapu sunu (Plectropomus leopardus). Laporan Teknis Akhir Kegiatan Anggaran 2015. Balai Besar Penelitian dan Pengembangan Budidaya Laut Gondol. Unpublish, $15 \mathrm{hlm}$.

Maskur, Muladno, \& Tappa, B. (2007). Identifikasi genetik menggunakan marker mikrosatelit dan hubungannya dengan sifat kuantitatif pada sapi. M edia Peternakan, 30, 147-155.

Ovenden, J. (2000). Development of restriction enzyme markers for red snapper (Lutjanus erythropterus and Lutjanus malabaricus) stock discrimination using genetic variation in mitochondria DNA. M olecular Fisheries Laboratory. Southern Fisheries Centre, 36 pp.

Sembiring, S.B.M., Haryanti, Suwirya, K., Wardana, I.K., Sutarmat, T., \& Yudha, H.T. (2012). Penggunaan penanda genetik tumbuh cepat untuk produksi calon induk kerapu sunu, Plectropomus leopardus dalam program seleksi. Jurnal Riset Akuakultur, 7(1), 01-09.

Sembiring, S.B.M., Haryanti, Muzaki, A., Wardana, I.K., \& Setiawati, K.M. (2014). Karakterisasi dan evaluasi penyandi gen cepat tumbuh pada induk kerapu sunu, Plectropomus leopardus turunan kedua (F-2). Laporan Teknis Hasil Penelitian Tahun Anggaran 2014. Balai Besar Penelitian dan Pengembangan Budidaya Laut Gondol. Unpublish, $19 \mathrm{hlm}$.
Sembiring, S.B.M., Muzaki, A., \& Wardana, I.K. (2015). Evaluasi reproduksi induk kerapu sunu, Plectropomus leopardus generasi kedua (F-2). Prosiding Forum Inovasi Teknologi Akuakultur, hlm. 201-209.

Setiadharma, T., Prijono, A., Giri, I N.A., \& Tridjoko. (2008). Manajemen pakan induk kerapu macan, Epinephelus fuscoguttatus untuk peningkatan pemijahan dan kualitas telur. Jurnal Riset Akuakultur, 3(1), 13-18.

Sugama, K., Rimmer, M.A., Ismi, S., Koesharyani, I., Suwirya, K., Giri, I N.A., \& Alava, V.R. (2012). Hatchery management of tiger grouper (Epinephelus fuscoguttatus): a best-practice manual. ACIAR. Canberra, 66 pp.

Suwirya, K. (2005). Spawning and larval rearing of coral trout at Gondol. SPC Live Reef Fish Information Bulletin. 13 January 2005, 52 pp.

Suwirya, K., Prijono, A., Hanafi, A., Andamari, R., Melianawati, R., Marzuqi, M., Sugama, K., \& Giri I N.A. (2006). Pedoman teknis pembenihan ikan kerapu sunu (Plectropomus leopardus). Balai Besar Riset Perikanan Budidaya laut Gondol, 18 hlm.

Suwirya, K., Prijono, A., Selamet, B, Sembiring, S.B.M., Hutapea, J.H., \& Haryanti. (2009). Performa calon induk kerapu sunu, Plectropomus leopardus hasil seleksi dari budidaya. Laporan Hasil Riset Anggaran 2009. Balai Besar Penelitian dan Pengembangan Budidaya Laut Gondol. Unpublish, $14 \mathrm{hlm}$.

Qu, M., Ding, S., Xu, X., Shen, M., You, Y., \& Su, Y. (2012). Ontogenetic development of the digestive system and growth in coral trout (Plectropomus leopardus). Aquacultur, 334-337, 132-141.

Watanabe, T. (1985). Importance of study of broodstock nutrition for further development of aquaculture. In Cowey, CB. (Eds.). Nutrition and Feeding in Fish. Academic Press. London, p. 396414.

Watanabe, T. (1988). Fish nutrition and mariculture. Department of Aquatic Bioscience. Tokyo, p. 191-233.

Yoseda, K., Yamamoto, K., Asami, K., Chimura, M., Hashimoto, K., \& Kosaka, S. (2008). Influence of light intensity on feeding, growth, and early survival of leopard coral grouper Plectropomus leopardus larvae under mass-scale rearing conditions. Aquaculture, 279, 55-62.

Zhang, D., Shao, Y., Jiang, S., Li, J., \& Xu, X. (2009). Nibea coibor growth hormone: its phylogenetic significance microsatellite variation and expression analysis. General and Comparative Endocrinology, 163(3), 233-241. 